\title{
KNOWLEDGE TRANSFER AND INNOVATION SUPPORTAS EXEMPLIFIED BY WIELKOPOLSKI ICT CLUSTER
}

\begin{abstract}
The global economy in the era of information society is characterised, among other, by changes within new organization models of business relationships. The development of information processing technologies is strongly correlated to new tools of the management process support. The operation of modern organizations within the global economy necessitates the adaptation of management methods and development strategies to new business conditions at the stage of digital transformation, which is gaining momentum at present. Solutions of the Information and Communication Technology (ICT) are the foundation of modern economic organizations in a knowledge economy. This is the case in particular in intelligent organizations, for which the advanced ICT infrastructure is the sine qua non condition for the effective knowledge management. This article presents the circumstances of the origin and operation of the IT sector cluster, as shown by the example of the Wielkopolski ICT Cluster, which is an outstanding project of this type in Poland. After the presentation of the core and features of the cluster, the achievements of WKT have been described in supporting innovation; moreover, the development directions have been identified in the context of internal and external determinants. The paper discusses the principal challenges in polish enterprise in form of clusters in the information society era. The second part of the article presents the results of Wielkopolski ICT Cluster.
\end{abstract}

Keywords:cluster, ICT, innovation, SME, information society.

\section{INTRODUCTION}

Changes of the business environment force modern organizations of the information society era to initiate adaptation mechanisms. The global economy is characterised, among other, by changes in the new models of organising business connections between enterprises. Such changes may imply the establishment of relations above their borders with the construction of networks of organizations and processes, which combine all participants of delivery chains, down to an end receiver. The advanced Information and Communication Technology solutions play an especially important role in this respect, being a basic factor of business competitiveness in introducing all types of innovation and knowledge transfer.

The purpose of this article is to show the circumstances of the establishment and the operation of the IT cluster, as presented by the example of the Wielkopolski ICT Cluster, which is among the best solutions of this type in Poland in the area of supporting the transfer of knowledge and innovation.

\footnotetext{
${ }^{1}$ Piotr Adamczewski, PhD, Institute of Management WSB University in Poznań, 61-895 Poznań, ul. Powstańców Wielkopolskich 5, tel. 61 655-3333, Adamczewski@ wsb.poznan.pl.
} 


\section{CLUSTER PURPOSE AND CHARACTERISTICS}

The explanation of cluster origin may be found generally in two dimensions:

- searching for the benefits of scale - internal and external advantages of scale coming with the positive external effects;

- the reduction of transaction costs - geographic and cultural costs of transactions together with costs of searching for information and knowledge.

The literature includes numerous cluster definitions ${ }^{2}$. For the purpose of this analysis, it is assumed that a cluster is a group of enterprises in adjacent geographic locations together with related institutions that are involved in a specific activity, connected due to their similarities and complementary.

The conditions for a cluster establishment are as follows:

- high intensity of businesses in an area;

- a large number of enterprises that conduct the same or substitutive activity;

- the occurrence of links (formal or informal) between enterprises, e.g. within subcontracting, cooperation, and outsourcing;

- the occurrence of a certain level of specialization;

- access to a research and development zone;

- access to human resources, suitable for the needs of a cluster;

- access to capital resources, originating primarily from the regional banking system.

The characteristic feature of industrial clusters is that enterprises that are gathered in them compete against each other, but also cooperate in the areas where it is possible to produce the effects of synergy in their joint actions (e.g. shared research and development work). Competition does not exclude mutual and beneficial interactions with other enterprises, and may become the drive for their development. This phenomenon is described as the cooperation in management. Such a situation is possible when the concentration of resources and competences specific in the sector reaches a critical mass, where a cluster becomes an attractive centre that gathers further resources around it. An example of this effect is the Silicon Valley, US, where the development of the IT sector has attracted the best computer experts from all over the world, making IT businesses located in that area increase their advantage over competition.

In the network of cluster connections, in addition to enterprises, there are also institutions and organizations, such as scientific centres, research and development units, and private organizations. Such a situation unlocks a major innovation potential of this organizational and spatial form of industry. The mutual connections between individual entities are often informal and are partly based on the high turnover of personnel inside a cluster.

The synergy effect of an industrial cluster involves primarily:

- know-how diffusion and personnel turnover within a cluster;

${ }^{2}$ R.Golej, Innowacyjność przedsiębiorstwa a jego uczestnictwo w klastrze technologicznym, [in:] Prywatyzacja, efektywność i finansowanie przedsiębiorstw, ed. J. Duraj, Wydawnictwo Uniwersytetu Łódzkiego, Łódź 2010, p. 34; M. Gorynia, B. Jankowska, Klastry a konkurencyjność i internacjonalizacja przedsiębiorstw - wyniki badań empirycznych, [in:] GOW - wyzwanie dla Polski, ed. J. Kotowicz-Jawor, PTE, Warszawa 2009, p. 56; K. Miszczak, Polityka rozwoju oparta na klastrach w przestrzeni kreatywnych aglomeracji, [in:] Dylematy rozwoju lokalnego i regionalnego na początku XXI wieku, eds. S. Korenik, A. Dybała, Wydawnictwo Uniwersytetu Ekonomicznego, Wrocław 2010, p. 77. 
- the increased productivity in a cluster owing to focusing resources;

- openness to innovation and the capacity to absorb it;

- attracting new resources and enterprises.

The synergy effects are also closely related to social trust or even social capital. The well-developed social environment is conducive to the atmosphere of trust in interpersonal contacts, especially business ones. Such trust significantly mitigates risks, which is particularly important for small businesses with few capital resources and low potential to influence its counterparties.

The following features are the basic characteristics of a cluster:

- relationships - the activity of cluster participants has to be targeted on a shared objective, to be able to take an advantage of their interaction;

- geographic proximity - cluster members have to operate nearby, so that there are the positive effects of penetration and use of the same resources;

- interaction - the mere geographic proximity or being oriented on a common goal is not sufficient - the interaction between entities is necessary;

- the number of entities - interactions have to take place among the sufficiently high number of participants, a so-called critical mass;

- interdependence - the relationships are based both on competition and partnership,

- high growth - the participants of a cluster feature high growth;

- export-oriented - a large number of participants sell their products and services outside a region or country.

According to the standard of the European Commission, the list of cluster attributes is as follows ${ }^{3}$ :

- members cooperate and compete against each other within a traditional or modern sector;

- there is a perceptible geographic focus in one or several regions;

- participants specialise in a specific sector and use shared technologies and skills;

- there is a cluster coordinator as an institutionalised characteristic.

Advantages derived by businesses from joining a cluster may be specified as follows ${ }^{4}$ :

- access to specialised and advanced resources, such as key skills and venture capital - in general such access increases the competitive capital;

- access to specialised suppliers, services and infrastructure, which usually raises the competitive capital as well;

- access to demanding customers, whose needs anticipate the changes on the international market, which generally enhances the competition strategy;

- the proximity of market rivals, who fight for the sector leadership, which also improves the competition strategy in general;

\footnotetext{
${ }^{3}$ J. Staszewska, Wykorzystanie klasteringu dla sukcesu rynkowego przedsiębiorstwa, [in:] Przedsiębiorczość, rozwój, zarządzanie, ed. R. Barcik, G. Biesok, M. Jakubiec, Wydawnictwo Naukowe Akademii Techniczno-Humanistycznej, Bielsko-Biała 2010, p. 98; Trendy rozwojowe inteligentnych organizacji w globalnej gospodarce, Wydawnictwo PARP, Warszawa 2009, p. 123.

${ }^{4}$ D. Wyrwa, Wplyw klastrów na konkurencyjność i innowacyjność regionów, [in:] Przedsiębiorczość, innowacyjność, foresight. Aspekty ekonomiczne, społeczne i ekologiczne, ed. L. Woźniak, Oficyna Wydawnicza Politechniki Rzeszowskiej, Rzeszów 2008, p. 59.
} 
- the closeness of related innovative sectors and institutions that support or are related to them - this feature also raises the competitive capital.

\section{CHARACTERISTICS OF WIELKOPOLSKI ICT CLUSTER (WIELKOPOLSKI KLASTER TELEINFORMATYCZNY (WKT))}

The Wielkopolski ICT Cluster is the shared initiative of the City of Poznan, the IT Institute of the Poznan University of Technology, the Poznań Supercomputer Network Centre, and IT businesses from the Poznan area. The cluster gained the form of an association in March 2008. The activity of the cluster is targeted at ${ }^{5}$ :

- scientific and research centres - ICT partnership; assistance in the commercialization of scientific studies; support in writing and coordinating large EU projects;

- ICT enterprises - facilitating the selection of technology partners; contacts with key players in the sector; support in market analyses, marketing and promotion; representing businesses on the national and European forums;

- administration entities - the technical verification of ICT concepts; developing feasibility studies; consulting in the selection of technologies and specialist ICT knowledge;

- ICT users - the collaboration in testing pilot solutions; assistance in the selection of technologies and technology partners.

The cluster became incorporated only a few months after the start of the formal cooperation. An association has been selected as an organizational legal form. This formula has numerous advantages, facilitating the collaboration among businesses. The association determines its objectives by itself, together with activity programmes and organizational structures, and adopts its by-laws that govern its operations. However, the most important advantage of this form of organization from the perspective of businesses is that its members do not assume any material liabilities. This aspect is particularly important when most WKT entities are micro and small enterprises, which are unwilling to join any initiatives that require their financial involvement. The cluster is a non-profit organization, and all income generated by its activities is dedicated to the fulfilment of its statutory objectives.

The WKT mission can be described as the establishment of cooperation foundations of the academics, businesses, and local government authorities within ICT. Our vision is the dynamic growth of ICT enterprises from the Wielkopolska region, based on the knowledge of research and development centres. To this purpose, we support the construction and performance of ICT implementation projects and try to internationalise the innovative products and services developed in consortia.

Members of the Cluster, including the Poznań University of Technology, the Poznan University of Economics, and the Poznań SupercomputerNetwork Centre, offer a substantial competence and computing back-up. At present, there are 67 ICT businesses among the Cluster members (including four big and seventeen medium enterprises). A large part of the members have taken part in the eight large shared innovation projects implemented so far, including with the use of own resources and, mostly, EU funds.

The cluster organises minimum two large sectoral events per year. For example, the ICT Wielkopolska Science and Technology Conference was held together with the Mayor

\footnotetext{
5 www.wklaster.pl.
} 
of the City of Poznań, and it attracted considerable interest - see Table 1. Businesses from the cluster regularly attend foreign economic missions and fairs, e.g. CeBIT in Hanover. In October 2011, WKT organised a prestigious international fair, Future Internet Assembly, held in Poznań by the European Commission in connection with the Polish presidency of the European Union.

The growth of the cluster by gaining new members is a part of its development strategy and proves its openness. WKT is among some of the largest such organizations in Poland, and is ranked in the group of organizations with up to 5,000 employees. This is due to the cluster structure, which is dominated by micro- and small enterprises. The mentality of such entities is often one of the main factors that inhibits the growth of the cluster, because of the low trust level and the lack of a collaboration vision.

Enterprises that belong to WKT operate primarily in the IT and telecommunication sectors, delivering modern hardware and software solutions, also for the public administration, the banking and medical sectors.

The Poznań City Office was among the initiators of the cluster establishment. It supports its operations and development actively, both in terms of finance and through promotion. The cluster has been invited to the consultation on the development strategy of the city of Poznań, which results from the policy adopted by the City Office of supporting the innovative ICT sector. The fact that the initiative of establishing the cluster did not come from entrepreneurs directly, could pose certain hazards at first, due to the lack of interest among businesses if there were no potential external funding of shared activities, e.g. with EU funds.

\section{PRACTICAL ACTIVITIES OF WKT}

The important achievements of WKT from the perspective of several years of its activity have been presented in Table 1. The cluster offers its services in the following sectors:

- ICTinadministration;

- new media;

- a medical section,

- telecommunication;

- business management;

- knowledge management;

- banking applications.

The project entitled Information and Computing Technologies Research Driven Cluster in Wielkopolska Province was aimed at initiating and strengthening the process of developing the organizational structures of WKT. The project was financed with the EU funds of the seventh framework programme. The mission of the project was to integrate ICT businesses and scientific centres from this sector to develop and implement innovative technologies and products in order to raise the economic competitiveness of the City of Poznań and the Wielkopolski Region. The detailed objectives of the project were as follows:

- to develop effective paths of preparinga group of new original technologies and final products, promoted as the 'regional speciality';

- to formulate the policy of reliable and effective cooperation among the partners in the cluster; 
- to create the scope of cooperation between science and business and to determine the demand of ICT business for scientific and development work and new technologies;

- to develop a consulting support system for the businesses active in the cluster;

- to establish an effective mechanism of promoting innovation and products offered by the cluster to external partners.

Table 1. Calendar of essential events at WKT

\begin{tabular}{|c|l|}
\hline Date & \\
\hline $\begin{array}{c}\text { June 2015 } \\
\text { March 2014 } \\
\text { July 2013 } \\
\text { June 2013 }\end{array}$ & $\begin{array}{l}\text { ICT Inspirations Conference - opening to new sectors; Benchmarketing } \\
\text { Seminar of PARP-Deloitte; ENOLL Exhibition in Manchester } \\
\text { Recruitment to the second edition of the coaching-consulting session dedi- } \\
\text { cated to entrepreneurs from the SME sector in Wielkopolska }\end{array}$ \\
\hline March 2013 & $\begin{array}{l}\text { Attending CeBIT 2013fair - the shared stand of the Cluster members and the } \\
\text { Wielkopolski Region }\end{array}$ \\
\hline April 2012 & Poznań Entrepreneurs Days with WKT participation \\
\hline March 2012 & $\begin{array}{l}\text { Attending CeBIT 2012fair - the shared stand of the Cluster members and the } \\
\text { Wielkopolski Region }\end{array}$ \\
\hline October 2011 & International exhibition Future Internet Assembly \\
\hline September 2011 & Participation of WKT in the Wielkopolski Clustering Conference \\
\hline June 2011 & $\begin{array}{l}\text { The establishment of the consortium of the Poznan Supercomputer-Network } \\
\text { Centre and ITTI Sp. z o.o. within ICT security }\end{array}$ \\
\hline March 2011 & $\begin{array}{l}\text { Attending CeBIT 2011 fair - the shared stand of the Cluster members and } \\
\text { the Wielkopolski Region }\end{array}$ \\
\hline November 2010 & $\begin{array}{l}\text { Enlarging the Cluster membership to 70 organizations, including 47 ordinary } \\
\text { and 23 supporting members }\end{array}$ \\
\hline October 2010 & $\begin{array}{l}\text { 2nd ICT Wielkopolska Conference: 'New Forms of ICT Business Collabora- } \\
\text { tion with the Public Sector' }\end{array}$ \\
\hline March 2010 & $\begin{array}{l}\text { Attending CeBIT 2010 fair - the shared stand of the Cluster members and } \\
\text { the Wielkopolski Region and the City of Poznań in hall 9 Future Park }\end{array}$ \\
\hline January 2010 & $\begin{array}{l}\text { 1st ICT Wielkopolska Conference: 'Science Stimulated Business. Develop- } \\
\text { ing Market Advantage owing to Innovative ICT Technologies' }\end{array}$ \\
\hline January 2009 & $\begin{array}{l}\text { Start of the 'ICT Wielkopolska' project aimed at developing the organiza- } \\
\text { tional and programme foundations of WKT and the stocktaking of ICT } \\
\text { potential in Wielkopolska }\end{array}$ \\
\hline
\end{tabular}

Source: www.wklaster.pl

The project tasks have been determined as follows:

- the effective coordination of the project in terms of organization and finance, resulting in the training of personnel who will manage the cluster office in the future;

- reaching a diagnosis of the research potential of the cluster - by establishing a database of present and planned innovation projects, determining the potential 
directions and areas of cooperation between science and business, in the implementation of the shared research and development projects;

- developing a competence map of the cluster, by creating a regional portfolio of ICT businesses and conducting the SWOT analysis for the cluster;

- developing the commercialization paths for the new technologies created within the cluster, e.g. by making a diagnosis of technological needs among ICT businesses interested in new solutions and developing the policy of protecting intellectual property;

- the promotion of the cluster and the project outcome, e.g. by creating the cluster brand and the establishment of the cluster portal.

The main expected result of the project was to establish the effective integration platform for the Wielkopolski ICT Sector within the shared research projects and the use of their results and promotion of the Polish and European ICT solutions.

The objective of another project, "Wielkopolska Broadband Network", is to provide the common, fast, and safe access to knowledge, electronic services, and information offered over the Internet, in particular in rural areas and in small towns, to the local communities, entrepreneurs, and public organizations in the Wielkopolskie Voivodeship.

The SWOT analysis ${ }^{6}$ can be presented as follows based on the six-years' history of WKT (according to the present studies of the management board and the author, as one of the WKT founders) ${ }^{7}$ :

Strengths:

- intense concentration of ICT sector businesses on a relatively small area (better cooperation potential);

- major scientific back-up facilities available to the cluster;

- the availability of qualified personnel;

- a strong position of the cluster in the region (the only cluster with this business profile in Wielkopolska);

- shared marketing activity in TV, press, and on the Internet;

- the laboratory potential available to the cluster;

- the participation of the cluster in international fairs (the potential to present the cluster, and exchange market information);

- the personal involvement of active people interested in the cluster development (in particular, the coordinator);

- the membership fees paid to the association by its supporting members;

- the close cooperation with research and development centres.

\footnotetext{
${ }^{6} \mathrm{~S}$ (Strengths), W (Weaknesses), O (Opportunities), T (Threats). The strengths and weaknesses include the internal conditions of the cluster, and opportunities and hazards concern external conditions, which are out of the cluster's control, as well as internal determinants, which may present a development opportunity or its limitation in the future.

7 Benchmarking klastrów w Polsce, PARP, Warszawa 2010, p. 62; S. Olko, Zarzadzanie procesami transferu technologii $w$ klastrach regionalnych, [in:] Restrukturyzacja w obliczu nowych wyzwań gospodarczych: zarządzanie - strategia - analiza, ed. R. Borowiecki, A. Jaki, Wydawnictwo Uniwersytetu Ekonomicznego, Kraków, p. 44.
} 
Weaknesses:

- no written strategy that defines the cluster objectives in the coming years;

- a low market activity of the cluster (no shared orders in the areas where they would be possible);

- poor communication and information exchange among cluster members;

- no awareness among all cluster members of the benefits that stem from cooperation;

- major differences between research interests among cluster participants, which prevent working on shared technologies;

- no comprehensive studies concerning the resources of the cluster;

- a small number of implemented projects;

- no competences in the technology transfer.

Opportunities:

- the considerable development potential of the sector in which the cluster operates;

- the potential fulfilment of shared orders of services by cluster participants, e.g. banking services, telecommunication;

- the establishment of the technology transfer centre;

- commencing the international cooperation;

- the market expansion opportunities;

- promoting the brand;

- activities that lead to the specialization of enterprises that belong to the cluster (the division of activities within task forces);

- the support for the activity and development of the cluster among public authorities, in particular the Poznań City Office;

- the well-developed infrastructure.

Threats:

- a change of the public finance direction and the discontinuation of supporting the cluster by public authorities;

- being dependent on public finance;

- limited access to funding from institutions of the business environment;

- 'brain drainage' and the outflow of talented young people to other regions;

- the failure of organising the effective process of technology transfer;

- the competition from other clusters with a similar business profile.

According to the analysis of the present activity of WKT, the following general conclusions may be drawn ${ }^{8}$ :

- the following positive aspects of the WKT operation can be identified:

$\circ$ the cluster is among the young but very promising clusters in Poland. The achievements of last years make WKT a leader of Polish clusters;

○ the visible successes of the cluster are appreciated, such as shared projects and visits to international fairs of the sector;

\footnotetext{
${ }^{8}$ P. Adamczewski, Transfer wiedzy dla wielkopolskiego sektora MSP $w$ perspektywie strategii i-2010, [in]: Transfer wiedzy i funduszu europejskich do sektorów gospodarki krajów UE, ed. J. Stacharska-Targosz, J. Szostak, Wydawnictwo Wyższej Szkoły Bankowej w Poznaniu, Poznań 2010, p. 235; Benchmarking, op. cit., p. 122.
} 
- some of the best practices applied by WKT include the close cooperation with the research and development sector and the public sector;

- the following drawbacks of the WKT operation can be identified:

$\circ$ the tangible benefits from the cooperation are not appreciated;

○ weak communication within the cluster;

$\bigcirc$ no sources of funding for the cluster operation;

- no written strategy of the cluster activity or development;

- difficulties in the organization of technology transfer.

Therefore, it is becoming expedient in a longer term to consider the possibility of becoming independent of the external sources of funding, e.g. by gaining a financial institution as a cluster member. Another important element is to raise the awareness of the benefits that come from cooperation (also in the international dimension), the development of the shared system of ordering services and the creation of the information exchange network. However, for this purpose it would be necessary to reinforce the area of technology transfer and formulate a precise strategy of WKT operation and development based on the shared business processes.

\section{CONCLUSIONS}

The demand for ICT technologies that support business processes of the knowledge economy keeps growing significantly, and this trend will continue in the years to come. Therefore, the clustering phenomenon in the Polish economy has a good chance to prove its advantages in such processes, in particular within the support of innovation and knowledge transfer. Therefore, the following conclusions may be reached:

- the concept of clusters is an example of enriching the classical state-supported market regulation with the elements of cooperation;

- the concept of clusters does not eliminate, however, the existence of the mechanism of rivalry and selection that is characteristic for the market economy; a cluster may be described in general terms as the "cooperation island in the ocean of competition";

- in modern market economics the market remains a rule, to which exceptions are made (compromising the rule); for example, in the form of clusters of collaborating organizations; however, such clusters are established in order to gain the competitive advantage over other organizations or clusters;

- the concept of a cluster supplements the missing element of the neoclassical economics and the development of an important thread of the new institutional economics - it introduces the element of trust to business partners into the analysis.

The progressing globalization of economy poses new challenges to enterprises. On the one hand, it requires higher efficiency, and on the other hand it discloses the potential of reinforcing own resources of knowledge and skills owing to the specialization and know-how that comes from the global intellectual system. The competitiveness and growth in economy are related directly to the growth of local innovation capacities as well as the availability of global resources. Clusters emerge as important forms of collaboration in knowledge transfer and innovation. The Wielkopolski ICT Cluster is an example of such a cooperation. 


\section{REFERENCES}

[1] Adamczewski P. (2010): Transfer wiedzy dla wielkopolskiego sektora MSP w perspektywie strategii i-2010, [in]: Transfer wiedzy i funduszu europejskich do sektorów gospodarki krajów UE, ed. J. Stacharska-Targosz i J. Szostak, Wydawnictwo Wyższej Szkoły Bankowej w Poznaniu, Poznań.

[2] Benchmarking klastrów w Polsce (2010): PARP, Warszawa.

[3] Golej R. (2010): Innowacyjność przedsiębiorstwa a jego uczestnictwo $w$ klastrze technologicznym, [in:] Prywatyzacja, efektywność i finansowanie przedsiębiorstw, ed. J. Duraj, Wydawnictwo Uniwersytetu Łódzkiego, Łódź.

[4] Gorynia M., Jankowska B. (2009): Klastry a konkurencyjność i internacjonalizacja przedsiębiorstw - wyniki badań empirycznych, [in:] GOW-wyzwanie dla Polski, ed. J. Kotowicz-Jawor, PTE, Warszawa.

[5] http://www.wklaster.pl

[6] Miszczak K. (2010): Polityka rozwoju oparta na klastrach w przestrzeni kreatywnych aglomeracji, [in:] Dylematy rozwoju lokalnego i regionalnego na poczatku XXI wieku, ed. S. Korenik, A. Dybała, Wydawnictwo Uniwersytetu Ekonomicznego, Wrocław.

[7] Olko S. (2010): Zarządzanie procesami transferu technologii w klastrach regionalnych, [in:] Restrukturyzacja w obliczu nowych wyzwań gospodarczych: zarzadzanie strategia - analiza, ed. R. Borowiecki, A. Jaki, Wydawnictwo Uniwersytetu Ekonomicznego, Kraków.

[8] Staszewska J. (2010): Wykorzystanie klasteringu dla sukcesu rynkowego przedsiębiorstwa, [in:] Przedsiębiorczość, rozwój, zarządzanie, ed. R. Barcik, G. Biesok, M. Jakubiec, Wydawnictwo Naukowe Akademii Techniczno-Humanistycznej, Bielsko-Biała.

[9] Trendy rozwojowe inteligentnych organizacji w globalnej gospodarce(2009): Wydawnictwo PARP, Warszawa.

[10] Wyrwa D. (2008): Wpływ klastrów na konkurencyjność i innowacyjność regionów, [w:] Przedsiębiorczość, innowacyjność, foresight. Aspekty ekonomiczne, społeczne i ekologiczne, ed. L. Woźniak, Oficyna Wydawnicza Politechniki Rzeszowskiej, Rzeszów.

\section{TRANSFER WIEDZY I WSPIERANIE INNOWACYJNOŚCI NA PRZYKLADZIE WIELKOPOLSKIEGO KLASTRA TELEINFORMATYCZNEGO}

Globalna gospodarka w dobie społeczeństwa informacyjnego charakteryzuje się m.in. zmianami w zakresie nowych modeli organizacji powiązań biznesowych przedsiębiorstw. Rozwiązania ICT (Information and Communication Technology) stanowią podstawę nowoczesnych organizacji gospodarczych. W szczególności dotyczy to nowocześnie funkcjonujących organizacji, dla których zaawansowana infrastruktura teleinformatyczna jest warunkiem sine qua non sprawnego działania z wykorzystaniem rozwiązań z zakresu zarządzania wiedzą. Zmieniające się dynamicznie uwarunkowania rynkowe wymuszają na organizacjach sięganie po nowe formy współdziałania, do których można zaliczyć organizację klastrową. 
Wyjaśnianie powstawania klastrów można dopatrywać się generalnie w dwóch wymiarach: poszukiwanie korzyści skali (wewnętrzne i zewnętrzne korzyści skali wraz z pozytywnymi efektami zewnętrznymi) oraz redukowanie kosztów transakcji (geograficzne i kulturowe koszty transakcji wraz kosztami poszukiwania informacji i wiedzy). Fenomen klastrów $\mathrm{w}$ polskiej gospodarce ma duże szanse na wykazanie swoich zalet $\mathrm{w}$ ich funkcjonowaniu, a w szczególności w zakresie wspierania innowacyjności i transferu wiedzy. W artykule ukazano przesłanki powstania i funkcjonowania klastra branży informatycznej na przykładzie Wielkopolskiego Klastra Teleinformatycznego, który należy do wyróżniających się rozwiązań tego typu w kraju. Po omówieniu istoty i atrybutów klastra scharakteryzowano dokonania WKT w zakresie wspierania innowacyjności i wskazano kierunki rozwoju w ramach uwarunkowań wewnętrznych i zewnętrznych. Celem artykułu jest omówienie zmian działania przedsiębiorstw wchodzących w skład Wielkopolskiego Klastra teleinformatycznego (WKT) i wynikających stąd korzyści biznesowych. W drugiej części rozważań odniesiono się do praktycznych dokonań omawianego klastra.

Słowa kluczowe: ICT, innowacje, klaster, MSP, społeczeństwo informacyjne.

DOI:10.7862/rz.2016.hss.57

Przestano do redakcji: wrzesień $2016 r$.

Przyjęto do druku: grudzień 2016 r. 